\title{
EXPERIENCES OF FRANCIS PARKER
}

\section{By Claude W. Dutton ${ }^{1}$}

In the courthouse at Davenport, Iowa, is a row of marble tablets telling and commemorating the names of many of the territorial settlers of Scott county. It is a democracy of names that are mingled and infixed in these stones; those of lustre with those unknown; names of distinction with names that are now only names. Of one, lying these many years in a solitary grave lost and unmarked in a clime yet wild and remote, there now is left his name upon these tablets, an old portrait, an older letter and a few vanishing memories retained by some of his descendants of his long journeying into new lands and the tragic end of his last pilgrimage. The letter, the picture, and his photograph, have been deposited with the Historical Department of Iowa at Des Moines as the only relics now existing of one who both in life and character was a good type of the Iowa pioneer. On the tablets mentioned above his name, Francis Parker, is followed by those of his wife, Rhoda C. (Chaplin), the younger of his two sons, Francis J., and all of his six daughters, Diantha, Mary, Rhoda, Celinda, Elizabeth and Laura. The year of their settlement in Scott county, as correctly given on the tablet, was 1840 , but Francis Parker and his son Francis J. had made a preliminary visit to the county in 1839 .

Francis Parker was born March 16th, 1788, in Clarendon, a village a few miles distant from Rutland, Vermont. He was the third son of Benjamin and Rachel (Wetherbee) Parker. He was married about 1810 to Rhoda, daughter of Moses and Mary (Platts) Chaplin.

Prior to January, 1814, Francis Parker removed from Clarendon to Rutland and in June, 1818, he was living

IClaude W. Dutton, son of Jerome and Celinda Dutton, and grandson of Francis Parker, prepared this manuscript at Wheatland, Iowa, in October 1921. The data used in this and other articles and sketches relating to Jerome Dutton and others of the Dutton and Parker families were notes and interviews unused in the preparation of, but having connection with family historical and genealogical publications. 
in Cavendish, Vermont, where he remained until about 1829. Beyond the record of the birth of some of his children in these various places there now is nothing else to indicate his residence in them, and nothing is known as to what incidents befell him or what pursuits he followed up to the time of his removal to Belmont (then Phillipsburg), Allegany county, New York, about 1829. Here he owned and worked a farm, built and operated a sawmill and later, without relinquishing either of these undertakings; took up another, the village "Clothing Works," where the woolen cloth spun and woven in the neighborhood was "fulled," dyed and finished. He followed these triple labors with great vigor but little profit.

Two of his nephews, Jonathan W. and George W. Parker, had gone to Davenport in 1836 . From these nephews came the good reports that impelled him to visit Iowa in 1839. He was accompanied by his son, Francis Jackson, and both returned to Phillipsburg the same year. In the fall of 1840 the whole family, with the exception of his oldest son, Harrison, emigrated to Iowa.

The end of this journey was the starting point of the next, begun nine years later. In the spring of 1849 he and his son, Francis Jackson, again set out westward; this time in an ox wagon with the California gold mines as the inspiration and objective point of the journey. They proceeded through southern Iowa and were among those who followed the Santa Fe trail to the Golden state. No incidents of this journey nor of his residence in California have survived. Two or three years later he left his son behind and embarked at San Francisco aboard a sailing vessel which occupied six months in its voyage around Cape Horn to New Orleans. He took "deck passage," but it was not long until the boats' officers gave him a cabin and invited him to dine at their table for the remainder of the trip. The vessel paused for a few days at Cuba-long enough for him to land on what he afterward told his children was "the most beautiful country 
I ever saw." Shortly thereafter he arrived at New Orleans from whence a river steamer brought him to Davenport.

\section{A "Covered Wagon" Trip}

Neither the profitless results of his California trip nor his 71 years withheld him from sharing in the Pike's Peak and Cherry creek "excitement." With no other "companion than his daughter, Rhoda, he set out from Scott county in 1859 . The two travelled in a covered wagon drawn this time by a team of horses. They first visited Cherry creek and were there when Denver was first taking form. Later the two were at Pike's Peak and at "California Gulch." It is the testimony of another of his daughters that the two "boarded two weeks with Kit Carson" sometime and somewhere during this period. His daughter, Rhoda, was married to Edward L. Gallatin in 1860 at Denver where she thereafter resided and at whose home he made his headquarters. It was from thence that he went to the "Pine Alto Gold Mines" in Arizona, from which the letter mentioned was written. Although this letter suggests his intention of making an early return to Iowa it cannot now be definitely determined when he arrived at his old home in Scott county. It is known only that he was there in 1863 or 1864 in one of which years the photograph previously spoken of was taken by Jared A. Frost at Wheatland.

It was also in one or the other of the years just named that he again went forth on his final journey across the plains. His motive in this, as in the other expeditions was the discovery of gold and the place of quest-New Mexico. ${ }^{2}$ When he made known this new project to his daughter, Celinda, she protested against it, urging that he was too old to undergo the hardships of such a journey and to evade the danger from the Indians. He replied

\footnotetext{
2See "Parker in America," p. 571. Eugene F. Parker affirms that the objective point of this journey was in Arizona, instead of New Mexico, and that the place where Francis Parker met his death was near some city in Arizona instead of Albuquerque, New Mexico, where all previous rumor and report located it.C. W. D.
} 
that he "liked such jants (jaunts)," that he "felt better when he was knocking around" than at any other time and that he had no fear of the Indians. He remarked that a younger man would be in more danger; that they were less likely to "hurt an old man who wasn't fit for war;" that he had never had any trouble with them and they had always treated him kindly.

- He set forward on the road on horseback and alone with only such equipment as could be carried by the horse he bestrode. As his children last beheld him there was no sign that his vigor, carriage or determination had been weakened by his more than 75 years. When well toward the end of his way he wrote back to his daughter, Laura, a letter now lost, written, as she recalls he mentioned, with a pointed stick because he had given his pen to an Indian who had taken a fancy to it. He told in this letter that shortly before it was written he had learned of the murder by the Indians of an emigrant family-a man and his wife and daughter-who, in their western progress of a year or thereabouts before, had rested for several days at the home of his son, F. J. Parker.

The next tidings that came from him were through a former neighbor, Canada McCullogh, who met him somewhere in the west and brought back word that he had taken up a mining claim which he believed to be valuable but was finding much difficulty in working it owing to the scarcity of water.

\section{Parker's LetTers to His Daughters}

Pine Alto Gold Mines

Arizona Territory, June 4, 1861.

Dear Daughters Celinda and Laura:

I write this letter to both of you, not having time to write separate letters. My health is not very good to-day, as I have a dysentery. I hope and pray that you and the rest of our friends are in good health. In the first place I will give you a description of our present situation. We are surrounded with the most barbarous tribe of Indians on the Continent, the Apaches. It is but 
a five days ago that they caught eleven men, hung them up by the heels, built a fire under their heads and burned them to death. There is but a few days passes but what some one is murdered. No one dares venture far from the town alone and none dares leave unless they go in large gangs. The greatest danger is between (here) and the Fort, which is about twelve miles, although there is danger for one hundred miles. I shall leave here as soon as $I$ can get away in safety.

I work hard and live poor. The reason is because there is not much here, no vegetables, no fruit and not very often meat. There is plenty of flour, whiskey, rum and brandy. No coffee, no tea, no sugar. I never was so poor in flesh. I was weighed last Sunday. My heft one hundred and seventeen. It is not to be wondered at that I am so low in flesh. I work hard; live poor; travel two miles every morning down hill to my work and up hill back again at night. The travel is worse than the days work.

I have twenty yards down Bear creek to work out if the water holds, and then I have two hundred and fifty yards in about half a mile of this place that will yield from five to ten cents to a bucket, but there is no water on it. I don't think there will be this season. There has not been four days rain here for five months. The water is pretty much dried up, hardly. water for house use. A'most all the miners have left on account of the water. There has been a company of soldiers stationed here awhile, but they have left. There has been a dreadful set of inhabitants here, outlaws from California and other places. They have mostly left and gone to join the Southern army. The pistol and the Bowie knife is the law, although they have always treated me with respect. Enough of this.

I have an excellent gold quartz lead that is very rich-eight hundred yards that. I bought and have it on record, and also a silver mine that is called very rich, but $I$ shall have to leave them all on account of the Indians. If it was not for them I would stay another year.

It is so dark where I am writing that I can't see how I write nor what I write. I don't request you to write, for there is-for there is-(no) knowing where I shall be. In one month from now I want you to lay a fine plate on and some good butter. We do not know but a very little of what that's going on in the states. I get no papers since the Overland mail stopped. It has got to be dark and I must stop writing.

Yours affectionately,

Francis Parker

Celinda Dutton

Laura Parker 


\section{Events Recalled by Celinda Dutton}

Memoranda of recollections by my mother, Celinda Parker Dutton, of events as told by her and recorded by me at different intervals-mostly within the period between 1900 and 1910 , or between her seventieth and eightieth year; although some were often repeated since my days of earliest childhood. Her mind and memory were then clear and vivid, and although she may have been in occasional error in the matter of exact time and location of particular incidents and places, I believe that in all material instances her recollection corresponds closely with the real circumstances.-CLAUDE W. DUTTON.

It must have been the latter part of December, 1865, while I was a Dr. Randall's Health Institute in Lyons that Jerome wrote me that he had learned from my folks on Rock creek that father had been killed. Someone had sent a letter and a newspaper to Jackson telling the circumstances of his death. I never saw either the letter or the newspaper but what was said in both of them was repeated to me by Jackson and Mary when I returned to Wheatland.

As they told me it appeared that sometime in October, 1865, father had started out for home from Albuquerque riding a pony and in company with the Government mail carrier. As the mail carrier had relays of fresh horses father soon fell behind and was obliged to travel alone. I do not know how far he had advanced from Albuquerque when some one, I do not know who, came upon his body on the ground beside the road, his pony-gone and his pockets emptied. He had been shot in the back it was supposed by Mexican outlaws who afterwards robbed him. The paper or letter also stated that he had been buried where he lay by a party of friendly Indians. This newspaper and letter conveyed the only tidings I ever had in regard to father's death. It does seem so strange that father should start home almost entirely alone through such an uncivilized country, but I suppose he was anxious to get to Denver, thinking to come through with Rhoda and her husband the next spring. What a pity that they did not let him know they were coming in the fall.

Father came to Belmont, or Phillipsburg as it was then 
called, the year before I was born, or in 1829. I. believe that he came there from Windsor, Vermont. Anyway I know that he had lived for several years in Windsor and kept a store there. At my first recollection we lived in a two-story, frame house that stood near the bank of the Genesee river. This house was the birthplace of myself and my sister, Elizabeth. The upper floor of the house was all in one large room but downstairs there was a kitchen, pantry, two bedrooms and what we called the "square room" that, like the kitchen, had a large fireplace in it and that we used for a sitting room. Here mother would bring her visitors, and among these I remember two or three old ladies who, as was the way in those times, always came carrying their work pockets in which they never failed to have some sweet biscuits or little' cakes for we children. A bridge crossed the river below our house and just above the bridge was a dam that furnished power for a sawmill, a gristmill and the clothing works that all stood one back of the other on the opposite side of the river.

\section{ENGAGED IN Cloth MAKING}

Father operated the clothing works which was an industry that most all of his brothers followed at one time or another. The purpose of the clothing works was not to make cloth but to finish and dye the rough woolen fabric that was spun and woven in the homes of the farmers and other residents of the neighborhood. I often went over to the works and watched father's "journeymen" and the other help at their work. The long strips of coarse cloth were put through all sorts of processes and machines. First they went into the fulling mill where they were soaked in strong soapsuds. Then they were rinsed, drawn out, stretched on tenterhooks and dried. Then they went through the teaseling machine that picked up the surface until it was all rough and fuzzy, and thence into the shearing machine where the fuzzy surface was trimmed off evenly. Next they were boiled in a great, round copper kettle of dye, and finally folded 
back and forth with a big square of cardboard between each fold and screwed down flat in a press. From this they came out large bolts of smooth, finished cloth. I remember that father made frequent trips to Troy for dye-stuffs and came back with quantities of madder, "fustic," and "Nicarauger," as he called it.

The clothing works were mostly left in charge of the journeyman, named Young. Father frequently dropped in but seldom did any work there. Most of his labor was applied and much of his time spent on his 400-acre farm that lay about two and a half miles from Belmont-I cannot say in what direction. He bought this farm before he moved his family from Vermont and it was to clear it off and work it that he came to Belmont. He named the place "Mount Hope." It was very hilly and covered with pine timber except a couple of fields that he had cleared off. These fields lay on two hillsides and one he called "Wheat Hill" and the other "Orchard Hill." This field he set out with apple, pear, plum and other fruit trees. Near these hills on a level piece of ground he built a log house to which we moved when I was five or six years old, and here my sister Laura was born. There was only one room in this house with a loft above. A large stone fireplace extended almost across one end of the room and the men, with the aid of handspikes, would roll huge logs into it that would burn for almost a week.

If the fire went out I had to run over before breakfast to old Zeb Noble's, as he was called, a neighbor who lived almost a mile distant, and bring back some live coals in a pan or a shovel to rekindle the fire. Mam was always worried until I got back for one of my little cousins, Mary Leilous, had her clothes catch fire while on a similar errand and was burned to death. In the fall and winter evenings father's hired men that worked in the sawmill would sit around the fireplace and while the crickets sang from the crevices in the stones would tell stories that we children listened to with great interest.

Close beside the house ran a little brook issuing from a spring. It was only a step across it and its clear, cold, 
swiftly flowing water was scarcely deep enough to cover the smooth little stones that formed its bed. The muddy creeks and "runs" in Iowa show nothing to compare with that clear little brook. I used to play along its edge and watch the' frogs sing with their throats puffed out or stray into the deep, still woods beside it to pick flowers or wintergreen berries. The intense quietude of this wood had a deep charm for me. I would wander alone for hours among its trees of pine, beach, hemlock and maple happy in the dreams of childhood or gathering beach nuts when they were ripe. One division of it was a grove of hard maple which we called the sugarbush and in the early spring while the sap was running our whole family would be at this spot all day and part of the night. The sap flowed from the trees into hundreds or little wooden troughs from which father collected it and poured it into a long, wide shallow pan. It was the work of we children to gather wood and keep a hot fire burning under this pan, in which the sap gradually boiled down into a thick syrup and finally granulated into maple sugar.

Sometimes the weather turned cold and the ground would be briefly covered with what father called a "sap snow." We celebrated these occasions by pouring a dipper full of hot, thick maple sirup into a white bed of frozen snow, thus making maple wax which is sweeter and of a better flavor than any candy you ever tasted. They were happy days for all of us at the sugarbush.

\section{The DaM and SaW Mill}

Not far from our house the little brook that I have mentioned before emptied in to what was called the North branch and this into Phillips creek. Before my recollection father had made a dam across Phillip's creek and built a sawmill beside it. The dam went out during a flood and the mill burned down, but he rebuilt them both. The sawmill was about half a mile distant from our log house but I often went down to it along a road that led through the tall pine timber and watched father and my brothers, Harrison and Jackson, and the hired men as 
they fed the saw logs against the long, upright saw that shot up and down like lightning as it ate its way through the $\log$. It was moved by a broad "overshot" waterwheel that turned with much splashing and a constant "flutter, flutter" as each blade came under the water flowing from the flume. Something about the mill was always getting out of fix and it seems to me now that father was as much occupied in tinkering it up as he was in running it.

Among our nearest neighbors at Mount Hope were the Benjamin, Feathers and Imer families and farther away an aristocratic old Englishman named Jeffrey Horne. He lived in a large two-story house with many windows set on top of a hill in a remote place isolated and shut in by the heavy pine woods. This place he called the "Hermitage," and one Sunday father took Rhoda and me by the hand and we walked out to visit it. It seems to me now that we walked for hours through the woods before we finally reached the house. Mr. Horne came out and greeted us very cordially. He looked just like an Englishman, rather portly with side whiskers and very dignified. He showed us all through his gardens, which were large and layed out with paths and walks in what I thought was great magnificence, and then took us in to the house. Here we met his wife, who was quite deaf and carried an ear trumpet over her arm. Before we went home his widowed daughter, Mrs. Thompson, set out a lunch. The solitude, loneliness and stateliness of the "Hermitage" deeply impressed me. There was much of mystery about the "Hermitage" and its proprietor. There were tales among his neighbors that he had held high station in England, but had been obliged to seek seclusion because he had "cursed the king."

Most of my recollections of our residence in York state are of the years when we lived in the log house at Mount Hope. Father was very vigorous and active and was always very busy, except in the evenings which he devoted chiefly to reading. With a candle on the table beside him he would sit until bedtime with the National 
Intelligencer or the Albany Journal before him-papers that he took for years. What he read in these papers was what he preferred to talk about rather than of the incidents and happenings of the neighborhood. He had great scorn for novel readers, and we girls had to keep out of his sight when we were reading the few novels that we could borrow. He took much interest in politics and was a strong Whig until he became an Abolitionist and later yet a Republican. He was a Universalist, but usually had little to say on religious topics, although in Vermont he once held a public debate on Universalism with an orthodox minister.

From what I have heard him say I know that his father was intemperate, but he never touched a drop of liquor nor used tobacco and was much opposed to both. For him there was no relaxation; it was all hard work. He was always robust and active and in good health, except for an occasional "spell" of rheumatism, which at times gave him great pain. It was always he who broke our colts to ride and harness, even when he had become an old man. He was scarcely up to the average height, but full-chested and of erect, compact build. His walk was brisk and spry. His eyes were blue and very keen and his hair brown, fine and rather thin. He never grew gray and was always smooth shaven. He wore glasses when reading. He appeared very neat when dressed in the "nice" suit that he kept for Sundays and special occasions. His last "nice" suit and his cane and all his remaining papers and personal belongings became Laura's after his death, and they were destroyed when her home in Calhoun county, Iowa, was burned. He kept bees and was a good hand at finding bee trees, and both in New York and in Iowa he would often employ Sunday in locating a bee tree. In his youth he played the clarinet. $\mathrm{He}$ was never a good provider for the family table or ward robe.

I have little definite recollection of anything father ever said about his own father, but I remember his oc- 
casional reference to his uncle Jonathan, ${ }^{3}$ whom he called "Uncle Jock." Uncle Jock lived somewhere in Vermont in a house with high, spacious rooms but with walls and ceilings unfinished, leaving the framework timbers exposed. From the massive rafters hung a row of bladders filled with herbs and household stores from the field and garden. Uncle Jock spoke with a peculiar accent which father thought was Welch, and when any of his suspended produce was needed for immediate use he would direct one of his sons to "take that lather and get that blather."

\section{The LuRe of the Circus}

One time while we were living at the log house a "caravan," as we then called it-a sort of forerunner of the circus-came to the village and remained several days. We heard of it, and Rhoda and I were on nettles to go but folks were prejudiced against shows and would not give their consent. We coaxed and teased persistently, though, and late on the last day of the show mam finally said we might go. She dressed us up in our finest clothes and off we started, first running over to Zeb Noble's and inviting Mary, a girl of our own age, to go with us. All three of us were in the keenest of happy spirits as we danced down the road toward the village. As we drew nearer we heard the distant music, the beating of drums, and the report of fire arms. We had almost reached the village when we saw father riding toward us. He stopped when he met us and after hesitating a minute told us that the show was over and it was useless to go on, that the guns and the music we heard were the signals that the caravan was preparing to leave. So we turned back with a crushing disappointment I shall never forget.

On a much later date some years after we had moved to Iowa, Mary Gue, our uncle Ben's sister, and I, moved by our youthful thirst for amusement, stole down the road toward Big Rock with the aim of seeing something of a

"Johnathan, Esq., who d. aged 63."-"Parker in America, D. 566. 
circus then exhibiting there-probably the first and last circus that ever held forth in that village. But we were so repressed by the current prejudice against going to shows, and were in so much fear of being observed in our approach to the scene of unhallowed revelry, that we turned back before we had obtained even a glimpse of the tent. I never visited a show until after I was married.

Our chief holiday in Phillipsburg was "Training Day" when everybody went down to the burg to watch the militiamen drill. Jackson was a member of the local company which was commanded by Capt. Uriah-Whitcomb. His uniform like all the others was made up merely of a green Spencer jacket and a green feather in his cap. The militiamen, with their rifles, first assembled at Aldrich's tavern. Then, led by a half-dozen fifers and drummers clad in red jackets and white trousers, and discoursing some such stirring air as "Jefferson and Liberty," they marched to a level piece of ground thickly dotted with stumps and called "The Flats," which was situated at the edge of the village. Here, after much drilling, they separated into two squads and engaged in a mock battle in which each side fought in Indian fashion from behind stumps. There was a great uproar of shouting and shooting and we all thought it a very thrilling and patriotic spectacle.

Uncle Washington Chaplin used to visit us occasionally in after years, but the only other member of mother's family that I ever saw was Uncle Daniel. I don't know where he lived but he and his wife came in a buggy and visited with us for several days and father and mam afterward returned the visit.

I never saw mam's father, Grandfather Moses Chaplin, but, Diantha, when a little girl, visited him at his home in Clarendon, Vermont. At that period he was a farmer. As she described him to me afterward he was a tall man with long features and an especially long chin. He wore his hair in a queue, and was very strict with his hired men; made them sit up straight at the table and insisted 
on good behavior. Sometimes when company was present he would set out a decanter of rum. He was firm and commanding in appearance. He took Diantha by the hand and led her out for a walk, during which he showed her a farm he had just purchased. On this occasion he presented her with a Hymn book, some leaves from which Diantha gave to me as a souvenir many years later, and these pages from the old book are now with the Historical Department at Des Moines.

I think mam must have resembled her father. Anyway her chin was noticeably long. She was of average height with very dark brown hair and blue eyes. Mary resembled her more than any other of her daughters. She was married when she was very young, and on account of her youth her parents were opposed to her marriage, and declined to enter the room where the ceremony was performed. She was a good talker, easy to visit with and enjoyed visiting. But, poor woman, she had little time to visit. She was always at work, it now seems to me. About her only time for rest was at night after we children had gone to bed. Then she would partake of her only indulgence-a single pipe-full of tobacco which she lighted with a coal from the fire-place and smoked the last thing before going to bed. Like father, she was a Universalist.

\section{PARKER'S NEAREST RELATIVES}

Father's sister, Aunt Polly Leilous, lived at first on a little farm near the burg, but later moved farther away to a place called the "Collins Settlement," but we used to visit back and forth once in a while. I remember Aunt Polly as a great talker, and Uncle John Leilous, because he was so stern with his children. If they talked loud or made any noise in playing he would exclaim: "Whist, now, whist," and they would become quiet instantly and talk in low voices.

I visited often at Aunt Sarah Parker's, who at first lived in rooms back of Uncle Alvin's store, although the 
family had moved into a fine new house before we left York state. Their four children bore the romantic names of Henry Earl, Clarissa Adriana, Frances Evelyn and Charles Carroll. Uncle Alvin was doing well even then and was prominent in the village: I recall him as a tall, spare, thin-visaged man, with a prominent nose, large eyes and thin, compressed lips. He seldom spoke and looked every inch the grasping Yankee of which he was a type. Aunt Sarah was a good house-keeper and always kept her children neatly dressed and showed that she felt the improving circumstances of the family. I recall one winter when, after I had made a two days visit at Uncle Alvin's, father came with an ox sled to take me home at dusk of the third evening. Before we were half way home some part of the sled broke down. Father tried to fix it, but it was dark and finally he said we would have to leave the sled until morning and walk home through the snow. Father asked if he should carry me but I assured him I could walk, and so we set off up the road in the dark, driving the two oxen, "Lamb," the white one and "Lyon," the red one, before us. It was not long before I became tired and father took me on his shoulder and carried me the rest of the way home. Then I discovered that mam's white wool shawl that I had worn around my shoulders had slipped off along the way and was missing. It was of a fine weave and had a border of beautiful red roses and it was about the nicest of mam's few adornments, so I was much grieved to lose it. Father thought he would find it on his way back for the sled in the morning, but he didn't and we never saw it again.

There was no school near the log house and after while Diantha took three of us girls back to the burg, partly in order that we might go to school and partly to board some of the hired help in the clothing works. We lived in some rooms on the upper floor of the clothing works and Mary, Rhoda and I went to school. Our first teacher was Frances Norton and afterward we went to Amanda Stimson, Betsy Whitcomb, Lorraine Howard and Marian Leland. Our way to school led back across the bridge, 
past the house where I was born and Uncle Alvin's store, to Table Knoll on top of which the school house stood. It contained but one room and the pupils sat on long benches, each bench elevated a little higher than the one in front of it. The benches faced the center of the room where the teacher's table stood and the boys sat on one side of the room and the girls on the other. Here I studied McGuffey's reader, Webster's spelling book, Peter Parley and Olney's geography.

Among my school-mates I remember Abigail and David Norton, children of Joseph Norton; Clementine Norton, a daughter of Ezenezer Norton; Elizabeth and Alice Horne, daughters of Charles Horne and granddaughters of Jeffrey Horne; Hannah Daniels, Mary Davis, Hannah Dickey, Charles and Elizabeth Aldrich and my cousin, Clarissa Parker, daughter of Uncle Alvin.

\section{ReCollections of PhillipsbuRg}

My brother Harrison was married in October, 1837, and I think it was the following spring that he and his wife moved into the log house and our folks came back to the burg again, making our abode in Uncle Alvin's old home, from which he had moved into his new house. It was a primitive little town then, made up of small frame houses scattered mostly along one street on the west side of the river. Foot-paths led along each side of the street, for there were no sidewalks and few fences. Aldrich's tavern, a square, two-story, unpainted structure, was the largest building and only social resort in town. The leading feature of every holiday was the ball given at this tavern and my sister, Diantha, always attended and was among the belles of the occasion. A stagecoach drove up the street every day and brought the mail. Uncle Alvin, I believe, was the postmaster and Squire Ebenezer Norton was justice of the peace. Walter Church, a rather foppish appearing young man of a family that owned an immense amount of land near the village, owned the stone grist mill but it was operated by a miller whose flouriness, fatness and jollity is yet 
well marked in my mind. There was a tannery somewhere in town, a blacksmith and wagonmaker's shop and a cabinet maker's shop, the latter owned by a man named Bartlett for whom John E. Owen worked when, in 1839 , he married my sister, Diantha.

Among other residents of the village or near-by country I recall the Dickey, Danieles, Hill, Van Campen and Orlin Smith families. There were a great many Nortons, old Doctor Norton, Benjamin and John being the oldest of that name. Michael was a son of old Doctor Norton and Squire Ebenezer a son, I think, of John Norton Emory and Henry Norton, who married my cousin, Nancy, daughter of Benjamin Parker-Nancy was the mother of Mrs. J. Demmer, of Belmont, were sons of Squire Ebenezer Norton. Most of these Nortons lived on the east side of the river.

With all of his hard work business matters had begun to go badly with father even before this time. Trade fell off to such an extent that he finally closed up the clothing works. It was probably in the fall of 1838 that we moved back in the country again, this time to a little house that stood near father's saw mill. Across the creek from the mill and the house was a high, steep bluff called Reed's Hill. Father bought some saw logs that had been cut on the top of this hill, and I remember seeing him and the men roll these logs to the crest of the hill and send them tumbling down into the water above the dam. It was a terrifying sight to see the huge logs roll crashing down the steep side of the hill and plunge with an awful splash into the water at its foot. Below the dam the creek was shallow and I often crossed it by stepping from one to another of the large stones in its bed, but the stream was broad with a large flow of water and I could scarcely believe Harrison when he told. us years later during a visit to Iowa that "all" the water in Phillip's creek could be run through a two-inch auger hole," and that the beautiful little brook near the log house was entirely dried up. 
It was about this time that Uncle Jonathan Parker came from Pennsylvania to visit us and, I suppose, father first took thought of moving to Iowa, or "the Black Hawk Purchase" as it was then called, where Uncle Jonathan's sons, Jonathan W. and George W., had gone a couple of years before. Money matters with father were getting worse and worse and I overheard Uncle Jonathan tell mam that "Frank needn't worry about anything he owes me," but other of father's creditors were not so kindly disposed. He had gone in debt heavily when he bought the Mount Hope farm from, I think, a Mr. Collins, and the time now came when he could not meet the payments on this debt. His inability to make these payments was, I believe, what finally decided him to pull up stakes and make a new start.

\section{The Move To Iowa}

There began to be much hopeful talk about Iowa at our home and all that winter father, Harrison and Jackson worked hard sawing lumber at the mill and hauling it on horse and ox sleds to the banks of a creek near the neighboring town of Cuba. The lumber was formed into a raft and one day the next spring father and Jackson gathered up their things, said "Good-bye" to us and started for Cuba where we knew they were to leave aboard the raft on their floating progress down the creek to the Allegheny river, thence to the Ohio, and onward to hunt a new home for us in Iowa. Somewhere along the Ohio river he sold the raft and I suppose that he and Jackson went the rest of the way to Davenport by steamboat. Father returned home the same fall, coming from Chicago to Buffalo by boat on the lakes. All the summer of 1840 we were busy in making preparations for moving to Iowa. A wagon fourteen feet in length was built. by the village wagonmaker especially for our journey, and father filled a long box with small fruit trees and shrubbery to set out in the soil of our new home. My sisters and I gathered and dried a goodly supply of wild raspberries and blackberries to take with us. Mary had 
- taught a term of school before we left York state and the money she received for teaching she invested in a flock of twelve or fifteen sheep. She left these sheep with Uncle John Leilous, who was to keep them on shares, but he never sent her a penny for any of the flock. Not long before we left I remember seeing some surveyors at work near our house and hearing our folks mention that they were surveying for the Erie railroad.

It was about the first of October when we started forth with father driving the horses attached to the long wagon with its homespun linen cover stretched over hickory bows and our dog "Bogus," or "Bose" as we usually called him, following behind. In the wagon with father and mam were Diantha, Rhoda, Mary, myself, Elizabeth and Laura, for Jackson and Diantha's husband had preceded us to Iowa, and Harrison never moved his home from Allegany county. In the wagon with us was an arm chair which had belonged to Grandfather Chaplin, a bureau, in which were six fine linen tablecloths which mam had spun and woven for each of her daughters, and her splint-bottom chair with the cross pieces of its back charred by the candle she used to hang on them to light her at her night time sewing or mending. I still have this chair, which mam sat in during all our long journey. Most of our household goods and the box of fruit trees were in another wagon driven close behind us by Uncle John Leilous. These goods were shipped aboard a sailing vessel at Buffalo for Chicago and we never found trace of them afterwards, although father, early that winter, drove back from our new home to Chicago in search of them. We drove through Friendship and Belfast at the beginning of our trip, and I was much disappointed to see such small and weather-worn villages, for they were spoken of so often in our family that I pictured them as large and active cities.

When we reached Erie father thought the load was too heavy for the horses and so he left the bureau and the tablecloths and other of our belongings to be forwarded 
to Chicago, but like the goods shipped from Buffalo we never found them again. When the weather was pleasant we camped out beside the road, boiling our tea over a camp fire and some of us sleeping on the ground-for we had no tent-and others in the wagon. In wet weather we stayed overnight in the homes of farmers and settlers along the way, where we always found a hospitable welcome. Once we came to a house on a hillside where grew an array of beautiful flowers which we all admired so much that father went up to the house and got some of the seed and roots of the owner, and these we afterward set out around our home in Iowa. At another time while we were travelling through some deep woods in Indiana father stopped the wagon and told us all to look forward up the road. A moment later a railroad train, with the engine smoking and puffing, glided out of the woods and across the road a half mile ahead of us-a vivid incident for us, for none of us but father had ever beheld the cars before. We came through Chicago, but all I remember of it is that it was a very swampy place.

\section{The FaMILY REaches IOWA}

Late one afternoon some days afterward we arrived in Rock Island where Owen met us and guided us to the ferry on which we crossed to Davenport. Uncle Jonathan was away from home and Aunt Naomi was staying with her daughter, Sarah Bonney, where we, too, remained over night. Late the next day we left Davenport, and it was after dark when we reached the end of our long journey at the home of George W. Parker near the northwest corner of the county. There was no road, nothing but a faint path and we would have lost our way if Bose hadn't gone on ahead and picked it out for us. We stayed at Cousin George's for a week and then moved into a log house that father rented of James Hale, located just where now stands the first farm house east and north of the first crossroads south of the Parker cemetery. Here we lived that winter and the summer and winter 
following, although Diantha and Owen moved into a near-by cabin of their own within a few months. My most distinct impressions of the new country were of its openness and absence of the deep forests that I was used to seeing, and the high winds that seemed to blow every day.

Among our near neighbors in our new Iowa home were the Pete Laughrey family, "Uncle Jimmy" Posten-we called his wife "Aunt Jimmy"-two jolly young men, John and Andrew Posten, who were the life of all of our parties and social gatherings, and Uncle Eli Goddard, a Methodist class leader, who presided at meetings held at his house and in the homes of his sons, George, Martin and Peter. down the creek.

There were about four acres in the little field that father had under plow the first year in Iowa. It was inclosed with a rail fence and sown to flax. Mary and I pulled the flax when the crop matured. The next year wheat was sown in this field and we were given much trouble by an angular old white cow who persisted in tossing aside the rail fence with her long horns and leading in the other cattle to feed on the grain. We were called out at all hours of the day or night to drive out the marauders.

Wild hogs were quite numerous in the timber. Their domestic forbears had escaped from the rude pens of the neighboring farmers and soon reverted to a wild state. At times when we girls would be walking through the woods they would start up unseen at our very feet and charge off into the underbrush with a startling "woof" which expressed an alarm equal to our own. They were common property and when pork was desired it was often obtained by the easy expedient of shooting a wild hog.

Diantha and Owen lived in a log cabin built on a hill about a half-mile southwest of the cemetery. Rock creek flowed around the foot of the hill and a foot-log supplied the only means of crossing the stream. The foot-log was carried off by every freshet and then we would have to 
wade the creek until Owen recovered the old log or made a new one, and he was never in much of a hurry about doing either one. A short distance north of this house was an Indian trail that came down diagonally from the northeast and continued for miles to the southwest. One day when I was at Diantha's a band of Indians came down the trail from the northeast. There were about forty of them, Indians, squaws and papoose, all mounted on ponies and trapped out in feathers and gay blankets. They trotted silently past the house and out of sight to the southwest. Near the trail and not far from Diantha's house was a little mound where a papoose had been buried. We always called it the "Little Indian Grave.".

Not long after we came to Iowa we found a young wild goose that had been injured and was unable to fly. It soon became domesticated and developed a strong attachment for mam. It became her inseparable companion and, like "Mary's little lamb," followed her wherever she went. Even when she went some distance to visit the neighbors it waddled, quacking solemnly, behind her. A similar instance came to my notice when Jerome and I were living at Leroy's not long after our marriage. One of Leroy's neighbors, an old man named Oerlein, had a pet sandhill crane, on which tall and angular fowl he had, with Teutonic regard, bestowed the corpulent and illfitting name of "Honnes." Wherever the old man journeyed at home or around the neighborhood Honnes stalked gravely along with him.

Sugar was very rare in those days and the usual source of "sweetenin" was New Orleans molasses. Even the molasses jug was frequently empty, and more than once mam made syrup by boiling down the juicy pulp of watermelon.

The land for what was then called the Pioneer, and is now known as the Parker cemetery, was donated by James Hale, father-in-law of "Burr" (C. B.) Snyder. The first person buried in it was a young man named Emmet Gould, who died in 1840. 
Once when father and Jackson were away from home on some long journey the rest of the family: mam, Rhoda, Mary, Elizabeth, and Laura were all taken sick with some kind of fever. I escaped it and had to do the best I could in taking care of the others. They were all thirsty all the time, it seemed to me, and they wanted the water as cold as they could get it. This made it necessary for me to make frequent trips to the spring, down near the creek some distance from the house. Quite often I would have to go after water in the middle of the night and I will never forget how terrified I was as I ran swiftly through the silent darkness to the spring and back. It was in the fall and as I sat at night alone in the house with all those sick ones around me the only sound that reached my ears was the steady, murmuring drone of the autumnal insects. To this day the annual fall concert of the insects gives me a feeling of intense loneliness.

When Mary began to teach school I was one of her first pupils. It was afterward that I attended school at Davenport and boarded with Uncle Jonathan and Aunt Naomi. Uncle Jonathan had a large library and was a great reader. He was a kindly and gentle man and lacked father's asperity. His views of novel reading were very different from father's, for he was an absorbed reader of fiction. The besetments and sorrows of the characters would often so affect him that he would weep profusely. This show of feeling did not add to my esteem of him, because I thought that tears disclosed a very un-Parker-like trait. It was at Uncle Jonathan's that I first read my favorite novel, "Earnest Maltravers." Other books from his library that I then read were "Clarissa Harlowe" and "The Castle of Otranto."

In 1853 or 1854 we young people organized the "Posten's Grove Temperance Watchmen's Club" which only lasted about a year. It was followed by the "Inland Literary Society" also called the "Atheneum," which met weekly at the schoolhouse. It was a quite ambitious 
organization and its members used to compose and read papers and hold discussions on various topics. I believe I still have an essay that I read at one of its meetings. All the Gues and Pounds belonged to it and it represented the best aims of the neighborhood. We used to enjoy its meetings but I think most of us liked a good dance better.

\section{THE MEANS FOR DECISION}

Horace Mann in Common School Journal of Iowa, January, 1841: If those momentous questions are ever to be correctly decided, which, for ages past have been submitted to the rack, the fagot, and the dungeon, and they could not decide-whch the blood of all the myrtrs has failed to decide-which the power of kings, aided by the wealth of nations, has failed to decide-if these questions are ever to be correctly decided, without supernatural agency, it must be by each party laying aside its exclusiveness, its pride, its infallibility, its contempt, and, by the union of all in some noble plan, to give to another generation fitter attainments, greater capacities, and that without which all other means are worthless-minds free from prejudice, and yearning after truth.

\section{MUST UNDERSTAND OUR PAST}

Dr. Raymond B. Fosdick, president of Rockefeller Foundation: No nation can manage its future which does not understand its past. Research and study are needed of the basis of our American habits and traditions-a wider knowledge of who we are and where and what we came from, a fuller interpretation of American life to enable us to comprehend what we possess today and on what our tomorrow can be built ... . The culture of the one world in the making is necessarily compounded on the diverse contributions of many peoples. Until a nation understands itself in relation to its own culture, it cannot intelligently harmonize and integrate its life into the larger pattern. 
Copyright of Annals of Iowa is the property of State of Iowa, by \& through the State Historical Society of Iowa and its content may not be copied or emailed to multiple sites or posted to a listserv without the copyright holder's express written permission. However, users may print, download, or email articles for individual use. 